\title{
Financial Literacy: Examining The Knowledge Transfer Of Personal Finance From High School To College To Adulthood
}

Dan Yates, University of Findlay, USA

Chris Ward, University of Findlay, USA

\begin{abstract}
Many states are now requiring high school students to be competent in the areas of economic and financial literacy. This is due to the recent escalation of bankruptcies, large credit card debt, and mortgage foreclosures in our society. This study examines how financial knowledge is transferred from the high school level to the college level and finally to the adult level. The authors reviewed the components of Blooms taxonomy at each level of learning. The Jump\$tart Survey, which is given to high school students, was evaluated. College curricula regarding personal finance courses were examined to determine if personal finance was required for graduation, or an option for general education credit, and whether it was required in a major. The final financial knowledge transfer can happen at the adult level through community programs. Breakdowns in the transfer of financial learning were noted through the progression from high school to adulthood. (Keywords: personal finance, financial literacy, high school students, college students, adult learning)
\end{abstract}

\section{INTRODUCTION}

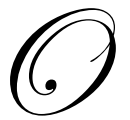

ver the past decade we continue to be informed about how poorly our society is doing in managing its finances. Whether it is the government (at all levels) spending too much or on a personal level such as excessive credit card debt, increased rate of mortgage foreclosures, lack of personal savings or retirement accounts, we all have to reassess how we handle our financial resources.

Perhaps we need to ask ourselves a few questions. Why are we having these problems? Is it due to ignorance as it relates to managing our personal finances? If so, what needs to change so that people make better personal financial decisions?

The goal of this study is to evaluate the content areas of personal financial education and determine the alignment as we examine the competencies at the high school, college, and adult levels. Also, we want to address and attempt to apply Bloom's taxonomy as a measurement of learning at each level.

The purpose of this research is to better understand the financial learning process by studying how knowledge is being "transferred" from high school, college, and to adulthood. Financial educators, policy makers/state mandates, and course curricula need to be better informed how knowledge is "threaded" through these levels.

This study is concerned on how adults acquire the knowledge, skills, and attitudes that are necessary to make prudent personal financial decisions. How do they learn behaviors about managing their financial matters? While we do not disregard that some good behaviors are taught at home, the focus here is to determine specific knowledge taught at different levels and determine common or consistent content areas and outcomes. 
The following statement captures the essence of what we believe describes the concept of financial literacy:

Financial literacy is about enabling people to make informed and confident decisions regarding all aspects of their budgeting, spending and saving and their use of financial products and services, from everyday banking through to borrowing, investing and planning for the future. (ANZ Survey of Adult Financial Literacy in Australia-May 2003, Executive Summary, pg. 1).

\title{
LITERATURE REVIEW
}

What is financial literacy? Although there are many definitions of financial literacy, the U.S. Financial Literacy and Education Commission (2007) defines financial literacy as

“.....the ability to use knowledge and skills to manage financial resources effectively for a lifetime of financial wellbeing." Our study embraces this definition since it utilizes the "application of financial knowledge" in making prudent decisions in managing one's financial resources. We believe this definition is relevant to high school students, college students, and to adults. Several studies have examined financial literacy. Each focused on different market segments.

\section{STUDIES RELATING TO HIGH SCHOOL FINANCIAL LITERACY}

\author{
National Council on Economic Education (NCEE) 2009 Survey
}

The National Council on Economic Education (NCEE) provides the only national set of data that tracks progress of economic and personal finance education. It now includes data on entrepreneurship education.

The NCEE, which has provided paper survey studies since 1998, now provides a web-based survey that solicits the chief executives of State Councils on Economic Education affiliated with the CEE; and the Social Studies, Business, and Family and Consumer Science education specialists in all 50 states (and the District of Columbia). The questions on the 2009 survey parallel earlier surveys.

The respondents that are contacted are considered experts with the knowledge to accurately answer the survey. The survey data is self-reported and sources would be contacted for verification purposes only if the data is significantly different from previous years or if different data is received from multiple sources within the same state.

The Personal Finance results of the survey are now included in the educational standards of forty-four states. At this time, thirty-four states now require these standards to be implemented. Thirteen states now require students to take a Personal Finance course (or Personal Finance included in an Economics course) as a high school graduation requirement. These thirteen states represent about $31 \%$ of the U.S. population. Nine states require the testing of student knowledge in Personal Finance. The poor response by the states to implement these standards is very disappointing as noted in the 2009 Survey of the States: Economic and Personal Finance Education in Our Nation's Schools (see appendix A and B). However, there is another national survey that tests for financial literacy.

The National Jump\$tart Coalition has surveyed high school seniors in forty-seven states for the past ten years. Below are the Jump\$tart Coalition's biennial financial literacy test results of high school seniors by percentage of questions answered correctly for the period 1997 through 2008 (Jump\$tart Coalition, Mandell 2009):

$\begin{array}{ll}\underline{\text { Year }} & \text { Percent } \\ 2008 & 48.3 \% \\ 2006 & 52.4 \% \\ 2004 & 52.3 \% \\ 2002 & 50.2 \% \\ 2000 & 51.9 \% \\ 1997 & 57.3 \%\end{array}$


The same 31 question survey exam was given to both high school seniors and full-time college students in 2008. In 2008, the financial literacy scores of high school students fell to its lowest level with a score of 48.3 percent while college students scored at 62.2 percent.

The survey instrument consists of 31 questions using a multiple choice format. The members of the Jump\$tart Coalition identified four key areas of coverage in their Personal Finance Standards: income; money management; saving and investing; and spending and credit.

The data gathered from the Jump\$tart surveys revealed several interesting facts. It was found that students who take a high school course in personal finance performed no better on the exam than students who did not take the course. Students with higher incomes tended to have higher scores. It was the fourth time that students from families with the highest incomes performed better than all other groups. It was noted that the survey results were also related to "parents' education level". The average score of students with neither parent completely high school was 44.2 percent and rose to 51.8 percent if at least one parent completed college. The results showed that students in the two lowest income categories performed significantly worse than higher income students across all subject areas. Mandell claims that families of students from higher income and better educated families may be placing a priority on the importance of financial literacy.

There was no evidence that high school students taking courses in either personal finance or money management improves their financial literacy. However, students who played a stock market game in class did significantly better on the exam than other students with a full semester's course in money management. Those who played the stock market game also had significantly higher financial literacy scores than those students that were planning to attend a four year college and have not participated in the stock market game.

Harris Interactive conducted an online survey for the National Council on Education (NCEE) in 2005 among a nationwide (U.S.) sample high school students $(2,242)$. The results of the survey noted that a majority of high school students do not understand the basic concepts in economics and this lack of knowledge impacts their ability to manage their personal finances and function in today's global economy.

A 24 question quiz in economics and personal finance was given to the survey group. The quiz covered 20 economic content standards developed by the NCEE plus additional concepts relating to personal finance. The students' average score on the quiz was $53 \%$ or "F". It was found that $60 \%$ of the high school students failed the quiz. The results of this quiz provide evidence there is room for improvement in economic and personal financial literacy for high school students.

Some of the other major findings of this study were:

- $\quad 50 \%$ of high school students say they have ever been taught economics in school (either in a separate course or as part of another subject)

- $\quad$ Most adults (97\%) believe that economics should be included in high school

- $\quad$ Most instruction of economics/personal finance appears to happen in 12th grade

- $\quad 75 \%$ of 12 th graders say they have been taught economics

- $\quad$ Students who have been taught economics in school are more interested in economics

- $\quad$ Economic understanding increases with age

- $\quad$ Ninth - tenth graders are least likely to get an "A" or "B"

- College graduates are 4 times more likely than those with only a high school education to get an "A" or "B" on the quiz

- Students who are not interested in economics are more likely to get an "F"

\section{STUDIES RELATING TO COLLEGE FINANCIAL LITERACY}

Peng, Bartholomae, Fox and Cravener (2007) examined how participating in a high school and/or college personal finance course influences investment knowledge. The study found that students who participated in a 
college level course with personal finance content had higher levels of investment knowledge. There was no significant relationship between taking a high school course and having investment knowledge. Participating in a college personal finance course appears to be more effective in enhancing investment knowledge than participating in a personal finance course at the high school level. Taking a personal finance course both in high school and in college was not correlated with higher investment knowledge scores.

The study notes the possibility of two factors of this finding. College students may receive more details on investment topics than in a high school level course. Secondly, the results may be partially explained by the "teachable moment" maxim as college students take on greater levels of their personal financial responsibilities such as paying bills, working, credit card usage, savings, and managing student loans. The knowledge gained through experiential learning may have more impact to the learning process of the college aged student.

In 2008, the Jump\$tart coalition also conducted its first national survey to measure the financial literacy of college students. The scores improved for every year of college with seniors averaging 64.8 percent. Mandell states that this is good news for the American college graduates as they are close to becoming financially literate and probably will be with more "life experiences".

The overall results of Mandell's study concludes that college students are far more financially literate than high school students and notes that literacy increases with each year of college. Financial literacy increases with the number of years of higher education and college seniors are "fairly financially literate". He adds that the Jump\$tart survey is really a measure of problem solving ability as opposed to mining financial facts. Knowing how to approach problems and conduct research are key to making decisions regarding personal finance. These critical thinking skills are perhaps more apt to be learned in college than in high school personal finance classes.

A different study by Cude, Lawrence, Lyons, Metzger, LeJeune, Marks and Machtmes (2006) set out to learn about college students' financial management practices and their attitudes about financial management. Their research was a multi-state project using an online survey at four universities from the fall 2004 through spring 2005. A total of 1,891 students participated in the survey. In-depth focus groups were conducted that met with about 10 students per group. Students responded to 10 survey items about the students' financial management practices. A "financial fitness" score was generated for each respondent. The results were used to classify the students as: "not financially at-risk," "somewhat at-risk," and "financially at-risk."

The results of the study found that students were more likely to be financially fit if they had higher GPAs or had married parents. Financially at-risk students were more likely to have credit cards, be a minority or a college senior. These findings support previous research.

One of the main conclusions from Cude et al's (2006) research is that some college students are not managing their finances well because of not adopting a set of recommended practices. Additionally, some "recommended" practices should be modified to more accurately match the ways college students responsibly manage their finances. Cude (2006) recommends that future researchers develop a scale of financial management responsibility that is fitting for college students' financial management options.

Other recommendations noted were the need for on-campus financial education programs, requiring a personal finance course be included as a general education requirement for graduation and the need for educational resources for parents. The students reported that their parents influenced their money management behaviors. Parents need to understand this influential role. Resources are needed to educate parents about how to discuss financial management issues to their children. Online resources, websites, etc. should be developed as a "one-stop" shop. Both parents and students could work together to find information about various financial topics. The study also recommended that campuses take a more "holistic" approach to students' financial needs by involving student organizations and parents in various campus offices such as financial aid, student affairs, career services, etc.

\section{STUDIES RELATING TO ADULT FINANCIAL LITERACY}

Harris Interactive also included a sample of adults $(3,512)$ in their online survey for the National Council 
on Education (NCEE) in 2005. The same 24 question quiz in economics and personal finance was given to the adults that were given to the high school students. The results of this quiz were adults earning a grade of $70 \%$ or "C" for economic/personal finance knowledge. It was noted that $25 \%$ of the adults failed the quiz. The results of this quiz provided evidence there is room for improvement in economic and personal financial literacy for adults.

The 2010 Financial Literacy survey was conducted by telephone within the United States by Harris Interactive on behalf of the NFCC (National Foundation for Credit Counseling) in 2010 among 2,028 adults ages 18+. The key findings are noted below:

- $\quad$ Financial Literacy: 34 percent of U.S. adults, or more than 77 million people living in America, gave themselves a grade of $\mathrm{C}, \mathrm{D}$, or $\mathrm{F}$ on their knowledge of personal finance. This suggests there is room for improvement with Gen Y adults at 39\% with the lowest grades and $43 \%$ of the Gen Y strongly agreeing that they could benefit from advice and answers to everyday-type financial questions.

- Budgets: Nearly 11 million adults (5 percent) don't know how much they spend on food, housing, and entertainment, and do not monitor their overall spending. Among the $56 \%$ of adults who do not have a budget, note negative attitudes about budgeting which may reinforce unhealthy spending behaviors.

- $\quad$ Spending: $51 \%$ or roughly 116 million people reported spending less than they were a year ago and nearly $23 \%$ are spending a lot less.

- $\quad$ Savings: One-third of adults (33 percent), or 75 million people, do not contribute to a retirement plan. $30 \%$ report that they have no savings and only 24 percent are now saving more than they did a year ago due to the economy. $48 \%$ of Gen Y adults report having no savings and $25 \%$ of those would charge an emergency type expense to a credit card or take out a loan.

- Debt and Credit Cards: 28\% (more than 64 million adults) admit to not paying all of their bills on time and more than 11 million adults ( 5 percent) report that their household carries credit card debt of $\$ 10,000$ or more each month.

- $\quad$ Credit Score: (65 percent) or 148 million people have not ordered a copy of their credit report in the past year despite it being free.

- $\quad$ Housing: $44 \%$ of adults (more than 100 million people) currently have a home mortgage and with $33 \%$ noting they did not understand some of the terms of their mortgage.

- $\quad$ Retirement: One-third of adults do not put any part of their annual household income toward retirement. Only $7 \%$ of adults save more than $20 \%$ of their income for retirement each year.

One of the key findings from the survey was that overall, financial literacy was low and most adults recognized the need for education. Seventy-eight percent of the adults stated they could still benefit from advice and answers to everyday financial questions from a professional.

Other findings were that the home was cited for the source for learning about personal finance education noting that $41 \%$ learned personal finance from their parents or at home. Only $6 \%$ cited learning personal finance in school. This would suggest the importance of incorporating personal finance into school curricula. Also, adults with lower incomes were more likely to grade themselves poorly in terms of financial knowledge.

Lusardi's (2008) research finds widespread financial illiteracy among the U.S. population. Most adults cannot perform simple economic calculations and do not have knowledge about the basic concepts of finance. Lusardi (2008) asserts that financial literacy affects financial decision-making and that ignorance about basic financial concepts can be associated with the failure to participate in activities such as retirement planning, stock market, and may cause poor decision-making behavior when borrowing money.

Lusardi and Mitchell (2006) wanted to combine data on financial literacy with data on financial behavior, so they began inserting questions measuring financial literacy into major surveys such as the 2004 Health and Retirement Study (HRS), the National Longitudinal Survey of Youth (NLSY), and the Rand American Life Panel (ALP). The benefit noted by the researchers was that it linked financial literacy to financial behavior. Lusardi and Mitchell (2006) conclude that only a limited number of questions can effectively be added to surveys to assess financial literacy. This constraint leaves us with the question, "what questions should be asked to determine the extent to which one possesses financial literacy?" 


\section{ISSUES IN MEASURING FINANCIAL LITERACY}

Huston (2010) reviewed the range of financial literacy measures used in research over the past 10 years and found that currently there are no standardized instruments to measure financial literacy. The purpose of Huston's work was to develop a more standardized measurement for financial literacy. The study reviewed 71 individual studies relating to personal finance, including terms such as financial literacy, financial knowledge or a closely related construct. In reviewing the studies for commonality of financial domain content, four main categories were identified: personal finance basics, borrowing, saving/investing, and protection.

It was found that the majority of the studies (72\%) failed to provide a definition of financial literacy and $47 \%$ of the studies used the terms financial literacy and financial knowledge synonymously. Almost nine of every ten studies did not provide an indication as to whether a respondent was "financially literate". Several studies made an attempt to make that indication. A study conducted by Volpe, Chen, and Pavlicko (1996) interpreted that a respondent with an investment IQ score of 70 or better as being investment literate. When considering if one is financially literate, there appears to be some contradiction from the Jump\$tart surveys. A score of $60 \%$ was needed to be financially literate per Mandell (1997), but for the 2009 Jump\$tart survey, a score of $75 \%$ was needed for being considered financially literate.

Huston's (2010) analysis of the studies found three main barriers to developing a standardized approach in measuring financial literacy. They were: the lack of conceptualization and definition of the construct financial literacy, content of the instrument, and instrument interpretation. Almost $75 \%$ of the studies did not explain the construct that was used and the majority used financial literacy and financial knowledge interchangeably. Only 25\% of the studies included all of the four finance components in their measurements as previously stated. The majority of the studies (88\%) did not include how to interpret the measurement results. Furthermore, there is no common or general understanding of the construct for financial literacy.

\section{CONCERNS FROM THE RESEARCH}

Although there are many surveys that collect data on behaviors pertaining to the handling of personal finances, our research found no evidence of a survey instrument that adequately measures financial literacy in the USA as it relates to measuring financial knowledge and the application of that knowledge in managing personal financial resources for adults. We found that the Jump\$tart survey measures various components of personal finance at the high school level and recently offered the survey to college students. The Jump\$tart Survey appears to be the only viable instrument available that attempts to measure the knowledge content of students (high school and more recently college students) in the area of personal financial literacy. However, to what extent does this instrument have external validity? Many states are now requiring personal finance and/or economics to be part of the high school curriculum. To what extent does the Jump\$tart Survey provide a worthy assessment measure for the various states?

\section{METHODOLOGY}

The above mentioned questions led us to pose the following research questions:

\section{Research question \#1: Does the Jump\$tart survey provide adequate assessment in measuring personal financial literacy?}

We examined the state of Ohio's recent requirements (Senate Bill 311) of requiring financial literacy of its high school students before graduation. "Each school shall integrate the study of economics and financial literacy, as expressed in the social studies academic content standards adopted by the state board of education under section 3301.079 of the Revised Code, ensuring that every high school student receives instruction in those concepts." This bill requires that Ohio high school students become financially literate before graduating from high school. Currently, the State of Ohio SB311 provides that financial literacy information can be integrated into a "stand alone" course or can be part of the content within a social studies course per SB311. There is no state examination in Ohio that requires high school students to pass in financial and economic literacy. There is no formally approved course 
of study. We reviewed the Jump\$tart website and used the Personal Finance Curriculum that was recommended for high school curriculum instruction (see appendix C) for analysis purposes (http://www.Jump\$tart.org/staterequirements-ohio.html). Although the State of Ohio is attempting to embed financial literacy into the curriculum, we could not find any concrete content outcomes. This raises additional questions:

- $\quad$ Do the questions from the Jump\$tart survey instrument provide an equal assessment of all the financial literacy content areas found on the Personal Finance Curriculum?

- $\quad$ Based on the Jump\$tart survey, what are the student performance results for each of the six financial literacy content areas as found in the Personal Finance Curriculum?

We analyzed the national Jump\$tart survey results to determine the student performance levels in all of the financial literacy content areas as found in the Personal Finance Curriculum which consisted of the following activities:

- Identified and assigned each of the 31 questions from the Jump\$tart survey to one of the six financial literacy content areas (Financial Decision-Making; Working and Earning; Budgeting, Banking, Saving/Philanthropy; Effective Use of Credit; Wealth Creation/Investing; and Risk Management). Table A shows each Jump\$tart survey question assigned to a financial literacy content area.

- $\quad$ Performed descriptive statistics (mean average and standard deviation) for each financial literacy content area (see Table B).

Research question \#2: To what extent do colleges offer personal finance in their curriculum as a general education requirement, a required course in a major; as a competency for graduation; or as an elective course?

A review of the catalogs of several area colleges was performed to collect data to answer this research question. A follow-up telephone survey to the registrar's offices of those colleges was conducted to verify our data taken from the catalogs.

Research question \#3: To what extent are the financial literacy content areas found in the Jump\$tart's Personal Finance Curriculum similar to the content areas found in college textbooks?

The purpose of this question is to examine any differences and similarities found in financial content areas at the high school and college levels. Also, can we determine the extent to which there is "progression" in financial learning from high school to college?

An analysis was conducted from four college level textbooks to compare the content areas from the Personal Finance Curriculum to the college textbooks.

Research question \#4: To what extent do adults use financial resources?

This question is a research study in itself. We examined various internet sites to identify possible financial sources to assist adults. We interviewed a local organization that provides financial learning resources to the community.

Research question 5: Using Bloom's taxonomy, to what the extent has knowledge, comprehension, application, analysis, synthesis, and evaluation been accomplished in learning at each level (high school, college, and adulthood)?

It has been proven that objectives and skills deemed important to learning are only achieved by moving from a simple (knowledge) to a more complex (evaluation) mode of thinking. This higher level of sophistication can generally be accomplished with specific activities that expect students to process information versus simply defining terms. 


\section{RESULTS}

Our study examined the scores from the 2008 Jump\$tart Financial Literacy Survey and analyzed the survey results by various financial literacy areas. Each question was reviewed and categorized into one of the six financial literacy content units as recommended by the Personal Finance Curriculum (Financial Decision-Making; Working and Earning; Budgeting, Banking, Saving/Philanthropy; Effective Use of Credit; Wealth Creation/Investing; and Risk Management).

Mean scores by unit and the number of questions per unit were then calculated, summarized and presented in the document. This study examined the 2008 Jump\$tart Coalition's biennial survey that was given to 6,856 high school $12^{\text {th }}$ graders in 40 states. The mean score was $48.3 \%$.

Table A: Shows each Jump\$tart survey question assigned to a financial literacy content area.

\begin{tabular}{|c|c|c|c|c|}
\hline Question & Unit(*) & Theme $(* *)$ & Topics & Score \\
\hline 18 & 1 & A & 5 & $67.9 \%$ \\
\hline 27 & 1 & B & 1 & $82.1 \%$ \\
\hline 2 & 2 & $\mathrm{C}$ & $1,2,3$ & $41.9 \%$ \\
\hline 7 & 2 & $\mathrm{C}$ & $1,2,3,4$ & $56.4 \%$ \\
\hline 13 & 2 & $\mathrm{C}$ & $1,2,3$ & $47.1 \%$ \\
\hline 21 & 2 & $\mathrm{C}$ & $1,2,3$ & $57.3 \%$ \\
\hline 24 & 2 & $\mathrm{~A}$ & 2 & $47.6 \%$ \\
\hline 5 & 3 & $\mathrm{C}$ & 5,8 & $55.8 \%$ \\
\hline 9 & 3 & $\mathrm{~B}$ & 3 & $40.1 \%$ \\
\hline 10 & 3 & $\mathrm{~A}$ & 1 & $60.2 \%$ \\
\hline 20 & 3 & $\mathrm{D}$ & 4 & $68.0 \%$ \\
\hline 25 & 3 & $\mathrm{~B}$ & 3 & $28.4 \%$ \\
\hline 31 & 3 & $\mathrm{D}$ & 1 & $27.3 \%$ \\
\hline 6 & 4 & $\mathrm{~A}$ & 3,5 & $47.7 \%$ \\
\hline 12 & 4 & A & 2 & $45.9 \%$ \\
\hline 15 & 4 & $\mathrm{~A}$ & 3 & $70.5 \%$ \\
\hline 23 & 4 & $\mathrm{~A}$ & 6 & $43.1 \%$ \\
\hline 28 & 4 & $\mathrm{~B}$ & 2 & $48.0 \%$ \\
\hline 29 & 4 & $\mathrm{~A}$ & 3 & $53.7 \%$ \\
\hline 1 & 5 & $\mathrm{~A}$ & 6 & $40.0 \%$ \\
\hline 3 & 5 & $\mathrm{~A}$ & 5 & $87.7 \%$ \\
\hline 4 & 5 & $\mathrm{C}$ & 3 & $35.8 \%$ \\
\hline 8 & 5 & A & 6 & $36.2 \%$ \\
\hline 11 & 5 & $\mathrm{C}$ & 1 & $16.8 \%$ \\
\hline 14 & 5 & A & 1 & $75.3 \%$ \\
\hline 16 & 5 & A & 6 & $51.1 \%$ \\
\hline 30 & 5 & $\mathrm{~A}$ & 5 & $32.5 \%$ \\
\hline 17 & 6 & $\mathrm{~A}$ & 4 & $40.4 \%$ \\
\hline 19 & 6 & $\mathrm{C}$ & 4 & $13.0 \%$ \\
\hline 22 & 6 & A & 2 & $36.8 \%$ \\
\hline 26 & 6 & A & 1 & $51.1 \%$ \\
\hline
\end{tabular}

(*) 1-Financial Decision-Making; 2-Working and Earning; 3-Budgeting, Banking, Saving/Philanthropy; 4-Effective Use of Credit; 5-Wealth Creation/Investing; and 6-Risk Management

(**) Refer to Appendix C (see "Themes")

Research question \#1: Table A shows each Jump\$tart survey question assigned to a financial literacy content area, the theme (see Appendix $\mathrm{C}$ for theme description), and the aggregate score of each question. Below are the results of this analysis: 
- Unit 1 (Financial decision-making) has only two questions appearing on the survey which relate to the theme areas of basic concepts and money. There were no questions pertaining to economic systems.

- $\quad$ Unit 2 (Working and Earning) had five questions appearing on the survey in which four questions pertained to the theme of taxes and one question on the value of education. There were no questions relating to career choices.

- $\quad$ Unit 3 (Budgeting, Banking, Saving/Philanthropy) had six questions on the survey. One question pertained to budgets and banking; two questions pertained to saving; one question pertained to spending; and two questions pertained to banking basics. There were no questions relating to philanthropy.

- $\quad$ Unit 4 (Effective Use of Credit) had six questions on the survey. Five questions pertained to understanding credit while one question related to credit cards. There were no questions relating to buying on credit.

- Unit 5 (Wealth Creation/Investing) had eight questions on the survey. There were six questions pertaining to savings vs. investments; two questions relating to investment options and market influence; no questions relating to time horizons and risk tolerance; and no questions relating to portfolio construction and management.

- Unit 6 (Risk Management) had four questions on the survey. Three questions pertained to insurance; one question related to fraud; no questions relating to identify theft; and no questions relating to consumer rights and responsibilities.

This analysis suggests that some content areas have more exposure on the survey than other content areas. The number of questions by content area on the survey range from two questions to eight questions (see Tables A and B). The authors believe there is an opportunity to enhance the Jump\$tart survey by providing more questions to adequately cover most of the theme areas for each content area. Due to some of the content areas receiving fewer questions, we feel the Jump\$tart survey does not equally assessment all content areas. We believe that each content area should have at least ten questions per content area that touch on the majority of the theme sections as noted in Appendix C.

In response to another research question: "Based on the Jump\$tart survey, what are the student performance results for each of the six financial literacy content areas as found in the Personal Finance Curriculum?", we analyzed the descriptive statistics to determined the mean average and standard deviation for each financial literacy content area/module (see Table B). Table A was used to record the percentage of correct scores by question number/content area and module/theme and topic. Below are the results:

- $\quad$ Unit 1 (Financial decision-making): This module had only two questions, but the mean score was $75.0 \%$. Although the question scores were high, the low number of questions pertaining to this area does not provide adequate assessment.

- $\quad$ Unit 2 (Working and Earning): This module had five questions appearing on the survey with the mean score of $50.0 \%$. The correct question scores for this module ranged from 41.9 to $57.3 \%$. As noted earlier, four of the five questions related to taxes and did not adequately assess the other three theme areas.

- Unit 3 (Budgeting, Banking, Saving/Philanthropy): This module had six questions on the survey with a mean score of $46.6 \%$. The correct scores for this module ranged from 27.3 to $68.0 \%$. Apparently students had difficulty with question \#25 (28.4\%) dealing with the reasons for saving and question \#31 (27.3\%) dealing with savings accounts. Five of the six theme areas had survey questions identified with it.

- $\quad$ Unit 4 (Effective Use of Credit): This module had six questions on the survey with a mean score of 51.4\%. As noted earlier, five questions pertained to understanding credit while one question related to credit cards use. The questions scores ranged from $43.1 \%$ on question \#23 (relating to the different types of credit) to the score of $70.5 \%$ which pertained to question \#15 relating to laws and credit regulation.

- Unit 5 (Wealth Creation/Investing): This module had eight questions on the survey with a mean score of 46.9\%. There were six questions pertaining to savings vs. investments which dominated the assessment of the four theme areas in this module. The correct scores ranged from $16.8 \%$ (see question \#11 pertaining to different types of investments) to $87.7 \%$ (see question \# 3 pertaining to goal setting).

- $\quad$ Unit 6 (Risk Management): This module had four questions on the survey with a mean score of 35.3\%. Three questions pertained only to insurance with no questions pertaining to the other theme areas. The scores on average for this module were low, especially for question \#19 (13.0\%) pertaining to resolving fraud. Question \#26 (51.1\%) was the high score for this module relating to life insurance. 
Table B: Descriptive statistics (mean and standard deviation) for each financial literacy area.

\begin{tabular}{|c|c|c|c|}
\hline Unit (*) & Number of Questions & Mean Score & Standard Deviation \\
\hline 1 & 2 & 75.0 & 10.04 \\
\hline 2 & 5 & 50.0 & 6.60 \\
\hline 3 & 6 & 46.6 & 17.17 \\
\hline 4 & 6 & 51.4 & 9.44 \\
\hline 5 & 8 & 46.9 & 23.57 \\
\hline 6 & 4 & 35.3 & 16.07 \\
\hline
\end{tabular}

(*) 1-Financial Decision-Making; 2-Working and Earning; 3-Budgeting, Banking, Saving/Philanthropy; 4-Effective Use of Credit; 5-Wealth Creation/Investing; and 6-Risk Management

Four of the six content areas performed at $50.0 \%$ or below. The content area of risk management appeared to be the weakest (35.3\%) for the high school students.

Analyzing the survey data by content area, then by theme, and then by topic provided valuable information in measuring student performance. It identifies specifically those areas that students need to improve upon. Once those areas are identified, then appropriate action can be taken.

Research question \#2: Next, we addressed the results of research question \#2: To what extent do colleges offer personal finance in their curriculum as a general education requirement, a required course in a major; as a competency for graduation; or as an elective course?

The results of analyzing seven different colleges/universities concerning the offerings and requirements of their personal finance course are shown on Table C. Only one college reported that the personal finance course was included in its general education course selections and no college/university required a personal finance course for graduation.

Table C: Personal Finance Class Requirements in Collegiate Curriculums

\begin{tabular}{|c|c|c|c|c|c|c|c|}
\hline \multicolumn{8}{|c|}{ Personal Finance Class Offerings/Requirements in Ohio Area College Curriculums } \\
\hline \multirow[b]{2}{*}{ Requirement } & \multicolumn{7}{|c|}{ College or University } \\
\hline & $\begin{array}{c}\text { Private \#1 } \\
\text { Univ. }\end{array}$ & $\begin{array}{c}\text { Private \#2 } \\
\text { Univ. }\end{array}$ & $\begin{array}{c}\text { Private \#3 } \\
\text { Univ. }\end{array}$ & $\begin{array}{l}\text { Private \#4 } \\
\text { Univ. }\end{array}$ & $\begin{array}{c}\text { Private \#5 } \\
\text { College }\end{array}$ & $\begin{array}{c}\text { Private \#6 } \\
\text { Univ. }\end{array}$ & $\begin{array}{c}\text { Large } \\
\text { Public Univ. }\end{array}$ \\
\hline $\begin{array}{l}\text { Offered as an } \\
\text { Elective } \\
\text { Course }\end{array}$ & Yes & No & Yes & Yes & Yes & Yes & Yes \\
\hline $\begin{array}{l}\text { General } \\
\text { Education } \\
\text { Status* }\end{array}$ & Yes & No & No & No & No & No & No \\
\hline $\begin{array}{l}\text { Required } \\
\text { Course/Major }\end{array}$ & No & No & No & No & No & No & No \\
\hline $\begin{array}{l}\text { Required for } \\
\text { Graduation }\end{array}$ & No & No & No & No & No & No & No \\
\hline
\end{tabular}

*Course will count as meeting one of the categories in the general education requirements.

Research question \#3: The purpose of research question \#3 was to examine any differences and similarities found in financial content areas at the high school and college levels. The analysis of the content areas of the four college level textbooks did contain all of the content areas suggested in the Personal Finance Curriculum. All of the textbooks discussed the topic of bankruptcy which was not specifically identified as a theme item on the Personal Finance Curriculum (see Appendix D), but could be included as an item for discussion within another theme area on the curriculum. None of the texts discussed the topic of "philanthropy" in any detail.

Research question \#4: As noted earlier, this question is a study within itself. We examined various internet sites to identify possible financial sources to assist adults and interviewed a local organization that provides financial 
learning resources to the community. There are many financial resource websites available for adults, teachers, and students. Appendix E identifies some websites that focus on financial learning and instruction.

A face-to-face interview was conducted with a local agency director that dedicates part of their services to educating adults in personal financial topics. This agency is temporarily funded through state grant monies. Its purpose is to promote and increase saving and debt reduction to produce financial stability among families through education and awareness facilitated by a broad base of community partners. Some of the community partners are other local agencies that assist needy families with paying their utilities and rent. After the second time of assisting these families, the adult member must complete a workshop through the agency that specializes in financial education. Examples of the education programs are: basic budgeting, debt reduction, credit repair, home ownership. The agency also conducts workshops such as a free tax clinic, spiritual lessons about money, consolidating and reducing debt, and other free activities. The main concern of the agency is the temporary funding and the lack of resources (manpower) to be more proactive in addressing financial literacy issues in the community.

Research question 5: Using Bloom's taxonomy, to what the extent has knowledge, comprehension, application, analysis, synthesis, and evaluation been accomplished in learning at each level (high school, college, and adulthood)?

In reviewing the findings from the Jump\$tart Survey for high school students, the results indicate that high school students performed poorly in all content areas with risk management receiving the lowest score. It appears that on average high school students are financially illiterate and were not able to demonstrate even the lowest level critical thinking skills.

We also reviewed the results of the Jump\$tart Survey for college students and found that college students scored higher than high school seniors on the survey and that college scores improved for every year of college with seniors averaging 64.8 percent. Although Mandell previously stated that college students are "fairly financially literate", they still fall below the mark of $75 \%$ which Mandell deems being "financially literate". In applying the criteria found in Bloom's taxonomy to the performance of the college students' tests results from the Jump\$tart Survey, it appears that while college students were able to demonstrate some higher order thinking skills, overall, there is room for improvement.

\section{LIMITATIONS}

In addressing research question \#1, we examined only one state in determining whether or not the Jump\$tart survey met the state's needs. Only seven colleges/universities were surveyed in determining the personal finance course offerings and requirements in regard to research question \#2. Our attempt is only to seek preliminary information regarding questions \#1 and \#2 with more in-depth research required in the future.

Limitations regarding research question \#3 consist of the lack of viable instruments in measuring financial literacy at any level as well as the lack of an adequate definition and construct of financial literacy.

In obtaining information for research question \#4, our attempt is again a preliminary examination of the personal financial resources available for adults. A limited number of websites were examined and only one faceto-face interview with an agency director was conducted. Again, this question has the possibilities for its own study and requires further in-depth investigation.

\section{DISCUSSION}

In reviewing the results pertaining to our research question \#1, we believe that the instrument used in measuring financial literacy of high school and college students does not provide adequate assessment of the content areas found in the personal finance curriculum. As noted in our results section (see tables A and B), more questions are required and we suggest at least ten questions per content area. This would provide for a broader range of questions for assessing purposes which exceeds the minimum number of questions of three to five items per content area as recommended by Kim and Mueller (1978). 
Based on the research findings and low competency scores, we assert that colleges should adopt into their curriculum a personal finance course to meet either a "general education" requirement or meet a "general competency" requirement. This would ensure college students would be more acquainted with the basic concepts areas regarding personal finance. We would encourage testing the financial literacy skills of all college graduates. This would be a bold position by colleges to demonstrate their high priority that all of their graduates were financially literate.

The purpose of research question \#3 was to examine any differences and similarities found in the financial content areas of the high school and college curricula. We found that the basic topic areas suggested by the Jump\$tart personal finance curriculum were also found within the college textbooks. This is encouraging information knowing that the same basic concepts are being emphasized at both levels. However, to what extent are the concepts being learned? We will continue that discussion later in this section.

As noted earlier, research question \#4 is a study within itself. We examined various internet sites to identify possible financial sources to assist adults and interviewed a local organization that provides financial learning resources to the community. There appears to be many, many resources available to the community to learn about various topics in personal finance. The problem is the "disconnect" between the people needing financial knowledge/training and the ability to link them to the organization or the website that could help them. This is an area that future researchers should address.

In applying Bloom's taxonomy, there appears to be a major meltdown in learning as we examine the competency levels of high school students, college students and adults. Due to the poor results from the Jump\$tart surveys (both high school and college students), it appears that financial knowledge has not been understood by these groups. Perhaps better measuring methods are needed, but in reviewing Mandell's data from past high school students' scores, those students have historically scored on average below $50 \%$. When recently tested, the college students' scores on the same survey were below $65 \%$. We believe that most high school and college students lack the basic financial literacy skills to make informed personal financial decisions.

At this time, there is no adequate testing instrument available to measure adult financial literacy. However, based on the levels of credit card debt, mortgage foreclosures, low saving amounts, and the results of the adult surveys mentioned earlier, we believe there is a real need to educate the adult population and be able to measure their level of financial literacy.

It is the conclusion of the authors there is a societal deficiency in personal financial literacy. It is a systemic problem. There are many excellent organizations and resources available that provide a wealth of information in the content areas of financial literacy. There is no indication that this information is being understood by our society either in high school, college, or adulthood. Our research found no evidence of any progression of financial literacy "being threaded" from the high school level through college and then into adulthood.

\section{RECOMMENDATIONS} our society.

Below are some recommendations that we believe will be the foundation for improving financial literacy in

- Development of an accepted conceptualization and definition of the construct financial literacy

- Development of a comprehensive personal financial literacy instrument for each level of analysis: high school, college, adults

- Agreement on the content areas of the personal financial literacy instrument and the instrument's interpretation

- $\quad$ Require a "stand alone" personal finance course for all high school students that utilizes active learning with engaging exercises and assignments

- $\quad$ Colleges adopt a policy that a personal finance course is required as a general competency for graduation

- $\quad$ Promotion of financial literacy workshops designed for adult learning 
The development and acceptance of a financial literacy definition, a financial literacy instrument, and an interpretation or rubric will improve the researcher's ability to measure financial literacy at the various levels as supported by Huston (2010). It will identify "gaps or deficiencies" in the content areas for each group. Once deficiencies are identified, then remedies can be developed for improving behaviors. The researcher will be able to assess the extent to which there is a progression of financial knowledge from high school to adulthood. Again, interventions can be applied to the specific level when gaps are revealed.

As mentioned earlier, there was no evidence that high school students taking courses in either personal finance or money management improves their financial literacy. However, students who played a stock market game in class did significantly better on the exam than other students with a full semester's course in money management. We recommend a "stand alone" personal finance course that engages the student through active learning exercises, interactive games, and critical thinking activities. Today's students want to be engaged.

The general competency requirement of a college personal finance course would again reinforce the financial knowledge concepts. It would provide another measurement point in determining the "threading or progression" of financial literacy at the college level.

Lastly, the promotion of workshops for adults that are specifically targeted to problems areas or aligned to deficiencies in financial knowledge is needed. The development of a "one stop" community learning center to address not only financial literacy but also other adult needs may prove to be beneficial. The accomplishment of these recommendations will take time and should be a high priority to future researchers interested in financial literacy.

\section{ACKNOWLEDGEMENTS}

We would like to express our gratitude to the contributions of Adam Radkey, an University of Findlay graduate student. His hours of researching and conducting statistical analysis on this project are greatly appreciated.

\section{AUTHOR INFORMATION}

Professor Ward holds the following degrees: University of Sarasota, EdD, Organizational Leadership; The University of Findlay, MBA and The University of Findlay, Bachelor of Science in Business Administration. She is also a Six Sigma Black Belt, a 2008 Ohio Partnership for Excellence Examiner, and completed the NxLevel Certification Course for Instructor Certification for teaching business plans. Her areas of research include student engagement, active learning, assessment and promotion and tenure. Dr. Ward is an Associate Professor of Business with The University of Findlay. Professor Ward brings her expertise from two Fortune 500 companies into the classroom teaching operations and logistics, marketing, management, strategy and policy, communications, and research.

Dan Yates is an assistant professor of business at The University of Findlay. His teaching interests include entrepreneurship, leadership, organization development, and business strategy. Yates holds a $\mathrm{PhD}$ degree in Management from Northcentral University. He also has a MBA from University of Dayton, a Master of Organization Development degree from Bowling Green State University, and a BS in Accounting from Tiffin University. He completed the NxLevel Certification Course for Instructor Certification for teaching business plans at the Innovation Center (Ohio University). He has 30 years industrial and governmental experience.

\section{REFERENCES}

1. ANZ Banking Group. (2003). ANZ Survey of Adult Financial Literacy in Australia. Melbourne: Roy Morgan Research.

2. Council for Economic Education (CEE). (2009). Survey of the States: Economic, Personal Finance \& Entrepreneurship Education in Our Nation's Schools in 2009. New York: Council for Ecnomic Education. 
3. Cude, B. J., Lawrence, F. C., Lyons, A. C., Metzger, K., LeJeune, E., Marks, L., et al. (2006). College Students and Financial Literacy: What They Know and What We Need to Learn. Eastern Family Economics and Resource Management Association Conference Proceedings, (pp. 102-109). Knoxville, TN.

4. Godsted, D., \& McCormick, M. H. (2007). National Adult Financial Literacy Research Overview. Indianapolis: Networks Financial Institute.

5. Grabmeier, J. (2007, August 9). Personal Finance Classes Help More in College Than High School. Retrieved August 27, 2010, from The Ohio State University Research News: http://researchnews.osu.edu/archive/finclass.htm

6. Huston, S. J. (2010, June 22). Measuring Financial Literacy. Journal of Consumer Affairs.

7. Kim, J.-O., \& Mueller, C. W. (1978). Factor Analysis: Statistical Methods and Practical Issues. Newbury Park: SAGE Publications, Inc.

8. $\quad$ Lusardi, A. (2008, June). "Financial Literacy: An Essential Tool for Informed Consumer Choice?". Dartmouth College, Harvard Business School, and NBER.

9. Lusardi, A., \& Mitchell, O. S. (2006). Financial Literacy and Planning: Implications for Retirement Wellbeing. Working Paper. Pension Research Council, Wharton School, University of Pennsylvania.

10. Making the Case for Financial Literacy-2010. (2010). Retrieved from JumpStart: www.jumpstart.org/assets/files/MakingtheCase2010\%201.doc

11. Marcolin, S., \& Abraham, A. (2006). Financial Literacy Research: Current Literature and Future Opportunities. Retrieved from http://ro.uow.edu.au/commpapers/223

12. National Council on Economic Education. (2005). What American Teens \& Adults Know About Economics. New York: National Council for Economic Education.

13. Peng, T.-C. M., Bartholomae, S., Fox, J. J., \& Cravener, G. (2007). The Impact of Personal Finance Education Delivered in High School and College Courses. Journal of Family and Economic Issues , 265284.

14. Survey of the States Report Reveals Pressing Need for Economic and Financial Literacy in U.S. School Systems. (2009, December 1). Retrieved September 8, 2010, from Council for Economic Education: http://www.councilforeconed.org/news/story.php?story id=174

15. Testimony of Dr. Robert F. Duvall President and Chief Executive Officer National Council on Economic Education before the House Committee on Financial Services. (2005, April 20). Retrieved September 8, 2010, from Council for Economic Education: http://www.councilforeconed.org/news/story.php?story id $=70$

16. The National Foundation for Credit Counseling. (2010). The 2010 Consumer Financial Literacy Survey Final Report. Silver Spring: The National Foundation for Credit Counseling; Harris Interactive Inc.

17. Valentine, G. P., \& Khayum, M. (Winter, 2005). Financial Literacy Skills of Students in Urban and Rural High Schools. The Delta Pi Epsilon Journal, Vol. XLVII; 1-10.

18. Volpe, R. P., Chen, H., \& Pavlicko, J. J. (1996). Personal Investment Literacy among College Students: A Survey. Financial Practice and Education , 6 (2), 86-94. 